\title{
EVALUATION THE PERFORMANCE OF STOCK FUNDS USING MULTI-CRITERIA DECISION MAKING METHODS
}

DOI: 10.17261/Pressacademia.2020.1351

PAP- V.12-2020(15)-p.70-71

Selim Baha Yildiz ${ }^{1}$, Musa Ovali ${ }^{2}$, Bercim Berberoglu ${ }^{3}$

${ }^{1}$ Manisa Celal Bayar University, Business Administration, Manisa, Turkey. baha.yildiz@cbu.edu.tr, ORCID: 0000-0002-0750-0556

2 Manisa Celal Bayar University, Business Administration, Manisa, Turkey. musa.ovali@cbu.edu.tr, ORCID: 0000-0001-6678-9719

${ }^{3}$ Manisa Celal Bayar University, Economics and Finance, Manisa, Turkey. bercim.berberoglu@cbu.edu.tr, ORCID: 0000-0002-2686-454X

To cite this document

Yildiz, S. B., Ovali, M., Berberoglu, B. (2020). Evaluation the performance of stock funds using multi-criteria decision making methods, PressAcademia Procedia (PAP), V.12, p.70-71.

Permanent link to this document: http://doi.org/10.17261/Pressacademia.2020.1351

Copyright: Published by PressAcademia and limited licensed re-use rights only.

\section{ABSTRACT}

Purpose- The aim of this study is to apply MCDM methods in addition to the traditional methods which are commonly utilized in evaluating the efficiency of stock funds. In this direction, starting from the fact that the normal distribution of stock returns, which is one of the assumptions of Modern Portfolio Theory, is mostly violated in practice, higher order moments are included in the objective functions of MCDM methods in addition to the first and second moments.

Methodology-. In this study, in addition to the traditional performance measurement methods such as Sharpe Ratio, Information Ratio, Treynor Ratio and Jensen's Alpha; Adjusted Sharpe Ratio and TOPSIS, MOORA from MCDM methods are utilized by including high-order moments in addition to the first and second moments in the objective functions. In the next step, the ranking process was carried out with respect to traditional and recommended performance evaluation methods. Then, the rankings were evaluated using Spearman Rank Correlation Test.

Findings- As a result of the analyses using the stock funds obtained from the TEFAS Turkey Electronic Fund Trading Platform for the period of 2018, 2019 and the first 9 months of 2020, ranking process is carried out using each methods' and these rankings are compared using the Spearman Rank Correlation Test. According to the results of the Jarque-Bera test, it is seen that the majority of the stock funds included in the sample do not show normal distribution. This situation strengthens our hypothesis and emphasizes the necessity of including higher moments in the analysis. According to Spearman's Rank Correlation Test results, strong relationships are found among the rankings obtained from traditional performance measurement methods. Moreover, it has been observed that the strength of the relationship between nontraditional methods and traditional methods is very weak. In other words, while the stock funds proposed by a traditional method were supported by other traditional methods, by making suggestions in a different direction TOPSIS and MOORA offered an alternative perspective considering the high-order moments.

Conclusion- In this study, it is shown that the higher order moments and alternative ranking methods can be used in evaluating the performance of stock funds. In the view of both performance measurement and the portfolio selection window, these methods are considered to be useful in the analysis of stock funds. Accordingly, this study is intended to provide a perspective for equity fund managers, fund investors, and researchers to evaluate the effectiveness of stock funds.

Keywords: TOPSIS, MOORA, high-order moments, stock funds, performance measurement methods. JEL Codes: G10, G11, G19

\section{HISSE SENEDI YATIRIM FONLARININ PERFORMANSININ ÇOK KRITERLI KARAR VERME YÖNTEMLERI ILE DEĞERLENDIRILIMESI}

\section{ÖZET}

Amaç- Bu çalışmanın amacı, hisse senedi fonlarının etkinliğini değerlendirmede kullanılan geleneksel yöntemlerin yanısıra, ÇKKV yöntemlerinin uygulanmasıdır. Bu doğrultuda, Modern Portföy Kuramı́nın varsayımlarından biri olan hisse senedi getirilerinin normal dağılımının pratikte çoğunlukla ihlal edildiği gerçeğinden hareketle, ÇKKV yöntemlerinin amaç fonksiyonlarına birinci ve ikinci momentlere ek olarak yüksek dereceden momentler dahil edilmiştir. 
Metodoloji- Bu çalışmada geleneksel performans ölçüm yöntemlerinden Sharpe Oranı, Bilgi Oranı, Treynor Oranı ve Jensen'in Alpha'sına ek olarak ayarlanmış Sharpe oranı ve ÇKKV yöntemlerinden TOPSIS, MOORA kullanılmış, ÇKKV yöntemlerinin amaç fonksiyonlarına birinci ve ikinci momentlere ek olarak yüksek dereceden momentler dahil ederek değerlendirilmiştir. Sonraki aşamada, her bir yönteme göre sıralama yapılmış ve analizler neticesinde elde edilen sıralamalar, Spearman sıra korelasyon testi kullanılarak karşılaştırılmıştır.

Bulgular- TEFAS Fon Bilgilendirme Platformu'ndan elde edilen hisse senedi fonlarının 2018, 2019 yılları ve 2020 yılının ilk 9 ayına ait verilerle gerçekleştirilen analizler neticesinde her bir yönteme göre sıralama yapılmış ve analizler ile elde edilen sıralamalar Spearman sıra korelasyon testi kullanılarak karşılaştırılmıştır. Jarque-Bera testinin sonuçlarına göre, örnekleme dahil edilen hisse senedi fonlarının büyük bir çoğunluğunun normal dağılım göstermediği görülmektedir. Bu durum, hipotezimizi kuvvetlendirmekte ve analizlere yüksek momentlerin dahil edilmesinin gerekliliğine vurgu yapmaktadır. Analizler sonucunda, geleneksel performans ölçüm yöntemlerinden elde edilen sıralamalar arasında kuvvetli ilişkiler tespit edilmiştir. Geleneksel olmayan metodlar ile geleneksel yöntemler arasında ise ilişkinin gücünün zayıf olduğu görülmüştür. Bir diğer deyişle, geleneksel bir metriğin önerdiği fonları diğer geleneksel metrikler desteklerken, TOPSIS ve MOORA gibi geleneksel olmayan yöntemler ise yüksek dereceden momentleri göz önünde bulundurarak alternatif bir bakış açısı sunmuştur.

Sonuç- Bu çalışmada, hisse senedi fonlarının performansının değerlendirilmesinde yüksek dereceden momentlerin ve alternatif sıralama yöntemlerinin kullanılabileceği ortaya konulmuştur. Hem performans ölçüm hem de portföy seçim penceresinden bakıldığında bu yöntemlerin hisse senedi fonlarının analizinde dikkate alınmasının yararlı olacağı düşünülmektedir. Bu doğrultuda, çalışmanın, hisse senedi fon yöneticileri, fon yatırımcıları ve araştırmacılar için hisse senedi fonlarının etkinliğinin değerlendirilmesi noktasında bir bakış açısı sağlaması amaçlanmıştır.

Anahtar Kelimeler: TOPSIS, MOORA, yüksek dereceden momentler, hisse senedi fonları, performans ölçüm yöntemleri. JEL Kodları: G10, G11, G19

\section{REFERENCES}

Alptekin, N., \& Şıklar, E. (2009). Türk Hisse Senedi Emeklilik Yatırım Fonlarının Çok Kriterli Performans Değerlendirmesi: Topsıs Metodu. Dumlupınar Üniversitesi Sosyal Bilimler Dergisi(25), 185-196.

Atan, M., Atan, S., \& Özdemir, Z. A. (2008). Türkiye'deki Bazı Yatırım Fonlarının Performanslarının Değerlendirilmesi. Gazi Üniversitesi İktisadi ve İdari Bilimler Fakültesi Dergisi, 10(2), 47-67.

Kıyıcı , U., Korkmaz, T., \& Uygurtürk, H. (2016). Türkiye'deki Bireysel Emeklilik Yatırım Fonlarının TOPSIS, VIKOR ve MOORA Yöntemleri ile Karşılaştırılmalı Performans Değerlendirmesi. Sosyal Bilimler Metinleri, 1-16.

Konno, H., Shirakawa, H., \& Yamazaki, H. (1993). A mean-absolute deviation-skewness portfolio optimization model. Annals of Operations Research, 45, 205-220.

Lai, T.-Y. (1991). Portfolio Selection with Skewness: A Multiple-Objective Approach. Review of Quantitative Finance and Accounting, $293-305$.

Markowitz, H. (1952). Portfolio Selection. Journal of Finance, 7(1), 77-91.

Oran, S. J., E. Avcl, M. Ashoor and O.F. Tan, (2017). An evaluation of Turkish mutual and pension funds' performances. PressAcademia Procedia (PAP), V.3, p.131-142.

Samuelson Paul A. (1970). The Fundamental Approximation Theorem of Portfolio Analysis in terms of Means, Variances and Higher Moments. The Review of Economic Studies, 37(4), 537-542.

Yildiz, S. B. (2020). Performance analysis of Turkey's participation and conventional indices using TOPSIS method. Journal of Islamic Accounting and Business Research. 